Thorax obpyriform or much narrowed posteriorly $\ldots \ldots \ldots \ldots 5^{2}$. 48. Thorax quadrangular or nearly $\ldots \ldots \ldots \ldots \ldots \ldots \ldots \ldots \ldots \ldots$ 4

Thorax about twice as long as wide, the sides more or less compressed or sinuate medially.

Head not wider than the thorax; abdomen ovate, subsessile, the second segment large, with two white spots.

(Africa.) . . . . . . A . . A A teromutilla,

50. Head somewhat large, but without a tooth on each side beneath, the hind angles rounded, not acute; eyes oval or oblong; antennal scape not specially long $\ldots \ldots \ldots \ldots \ldots \ldots \ldots \ldots \ldots \ldots \ldots \ldots \ldots \ldots \ldots \ldots$ I. Head large, with 'a tooth on each side beneath, the hind angles acute; eyes oval; antennæ rather widely separated, the scape long, the third joint very long; mandibles long, narrow, arcuate and bidentate at apex. (North America.)........Myrmilloides, André. 5. Mandibles 3 -dentate; third antennal joint only about twice as long as the fourth, or as long as joints 4 and 5 united. (Europe, Africa, Asia.)............................ Myrmilla, Wesmael. Mandibles acuminate at apex, with a tooth within before apex, never tridentate; third antennal joint more than twice longer than the fourth. (Europe, Africa.)........... Edrionotus, Radoszkowski. (Type Mutilla capitata, Lucas.) 52. Head not wider than the thorax, strongly concave beneath, the margins rimmed; second abdominal segment anteriorly depressed, the depression limited by an oblong cushion.

(Asia.) . . . . . . . . . . . . . . Platymutilla, Andrê.

(Type P. quinquefasciata, André.)

\title{
A NEW JOINT-WORM PARASITE FROM RUSSIA.
}

By William H. AShmead, M.A., D.Sc., Washington, D. C.

Homoporus Vassiliefi, sp. nov. - $q$-Length, $2 \mathrm{~mm}$. Head and thorax bluish, finely, closely punctured, the face and the pleura with a greenish metallic lustre, the metapleura decidedly brassy; antennæ brown, the scape yellow; legs concolorous with the thorax, the hind coxæ with a metallic greenish fringe, the apices of all femora, all tibiæ and tarsi, except the last joint, yeliow, the last joint dark fuscous; wings hyaline, the nervures brown, the stigmal vein two-thirds the length of the marginal, the 
postmarginai vein very nearly as long as the marginal ; abdomen aeneous black, tinged with metallic green basally at the sides, ovate, somewhat pointed at apex, very little longer than the thorax.

Type.-Cat. No. roro, U. S. N. M.

Host.-Hym.: Isosoma eremitum, Portschinsky.

Hab.-Oufa, Russia. Described from a single specimen, received from Mr. Ivan Vassilief, of St. Petersburg.

Two of the Russian joint-worms described by Portschinsky, namely, Isosoma apterum and $I$. eremitum, should be relegated to the genus Philachyra, Haliday.

\section{CONCERNING GASTROPHILUS EPILEPSALIS, FRENCH.}

Mr. Washburn's note in the November number (p. 320) induces me to state that Gastrophilus epilepsalis, French, is no Gastrophilus at all; in fact, not the larva of an Estrid. The figure shows that it is a Muscid larva, very probably of Calliphora, certainly so if the figure is correct. The species cannot be identified until more of these forms are reared. French's figure indicates that it is very close to the European $C$. vomitoria as figured by Piepers. There is no definite character known to identify Estrid larvæ, but the larvæ of some Muscida can be separated from the Estridæe. The larvæ of Calliphora differ somewhat in the structure of the mouth from any known Estrid larvæ. That Prof. Washburn had a Gastrophilus is quite possible from the habits; but it is not the $G$. epilepsalis, French.

Nathan Banks.

\section{CORRESPONDENCE.}

SiR,-Please insert the following addition to my paper on Isodontia, published in the Canadian Entomologist for October, I903 (P $27 \mathrm{I}$ ):

Isodontia macrocephala, var. cinerea. Described from four specimens taken at Enterprise, Fla.; Columbia, S.C.; Texas, and one without locality. These cotypes are in the collections of the U. S. National Museum, American Entomological Society, Mass. Agricultural College, and Dr. W. H. Ashmead, the collections from which I received them.

H. T. FERNALD. 


\section{$2 \mathrm{BHL}$ Biodiversity Heritage Library}

Ashmead, William H. 1903. "A new joint worm parasite from Russia." The Canadian entomologist 35, 332-333. https://doi.org/10.4039/Ent35332-12.

View This Item Online: https://www.biodiversitylibrary.org/item/22193

DOI: https://doi.org/10.4039/Ent35332-12

Permalink: https://www.biodiversitylibrary.org/partpdf/26672

\section{Holding Institution}

MBLWHOI Library

\section{Sponsored by}

MBLWHOI Library

\section{Copyright \& Reuse}

Copyright Status: NOT_IN_COPYRIGHT

This document was created from content at the Biodiversity Heritage Library, the world's largest open access digital library for biodiversity literature and archives. Visit BHL at https://www.biodiversitylibrary.org. 